\title{
"The development of small business as a source of formation of local budget revenues in Ukraine"
}

\author{
Olha Hryhorash (D https://orcid.org/0000-0002-8089-3755 \\ R https://publons.com/researcher/1976980/olha-v-hryhorash/ \\ Maxim Korneyev (D https://orcid.org/0000-0002-4005-5335 \\ AUTHORS \\ R http://www.researcherid.com/rid/B-7032-2018 \\ Yevgeny Leheza (D https://orcid.org/0000-0001-9134-8499 \\ Liliya Zolotukhina (D https://orcid.org/0000-0002-4453-3576 \\ Tetiana Hryhorash (D https://orcid.org/0000-0002-3000-1683 \\ [R https://publons.com/researcher/1976982/tetiana-f-hryhorash/
}

Olha Hryhorash, Maxim Korneyev, Yevgeny Leheza, Liliya Zolotukhina and ARTICLE INFO Tetiana Hryhorash (2018). The development of small business as a source of formation of local budget revenues in Ukraine. Investment Management and Financial Innovations, 15(1), 132-140. doi:10.21511/imfi.15(1).2018.12

DOI http://dx.doi.org/10.21511/imfi.15(1).2018.12

RELEASED ON Thursday, 15 February 2018

RECEIVED ON Thursday, 11 January 2018

ACCEPTED ON

Friday, 02 February 2018

\section{(oc) EY-No}

LICENSE

This work is licensed under a Creative Commons Attribution-NonCommercial 4.0 International License

JOURNAL

"Investment Management and Financial Innovations"

ISSN PRINT $1810-4967$

ISSN ONLINE $1812-9358$

PUBLISHER

LLC "Consulting Publishing Company "Business Perspectives"

FOUNDER LLC "Consulting Publishing Company "Business Perspectives"

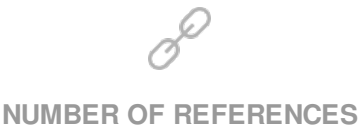

24
NUMBER OF FIGURES

4
ニニュ

NUMBER OF TABLES

1

(C) The author(s) 2023. This publication is an open access article. 


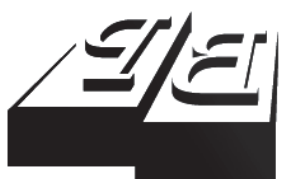

BUSINESS PERSPECTIVES

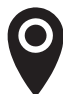

LLC "CPC "Business Perspectives" Hryhorii Skovoroda lane, 10, Sumy, 40022, Ukraine

www.businessperspectives.org

Received on: $11^{\text {th }}$ of January, 2018 Accepted on: $2^{\text {nd }}$ of February, 2018

(C) Olha Hryhorash, Maxim Korneyev, Yevgeny Leheza, Liliya Zolotukhina, Tetiana Hryhorash, 2018

Olha Hryhorash, Ph.D. (Economics), Senior Lecturer of the Department of Finance of Business Entities and Insurance, Faculty of Finance, University of Customs and Finance, Ukraine

Maxim Korneyev, Doctor of Economic Science, Associate Professor, Professor of the Department of International Economic Relations, Faculty of Management, University of Customs and Finance, Ukraine.

Yevgeny Leheza, Doctor of Law, Associate Professor, Professor of the Department of Administrative and Customs Law, Faculty of Law, University of Customs and Finance, Ukraine.

Liliya Zolotukhina, Ph.D. in Law, Associate Professor, Professor of the Department of Civil Law Disciplines, Faculty of Law, Dnipropetrovsk State University of Internal Affairs, Ukraine.

Tetiana Hryhorash, Senior Lecturer of the Department of Finance of Business Entities and Insurance, Faculty of Finance, University of Customs and Finance, Ukraine.

\section{(ㄷ)(1) $(9$}

This is an Open Access article, distributed under the terms of the Creative Commons Attribution-NonCommercial 4.0 International license, which permits re-use, distribution, and reproduction, provided the materials aren't used for commercial purposes and the original work is properly cited.
Olha Hryhorash (Ukraine), Maxim Korneyev (Ukraine), Yevgeny Leheza (Ukraine), Liliya Zolotukhina (Ukraine), Tetiana Hryhorash (Ukraine)

\section{THE DEVELOPMENT OF SMALL BUSINESS AS A SOURCE OF FORMATION OF LOCAL BUDGET REVENUES IN UKRAINE}

\begin{abstract}
The timeliness of the research is conditioned by the need to analyze the development of small business as an indicator of the development of the middle class, which characterizes the socio-economic level of the country in general and contributes to strengthening its financial situation. The article contains the analysis of the small business development and its influence on the formation of local budget revenues in Ukraine. Based on the correlation and regression analysis, the statistical series of the sales volume of small business was aligned, taking into account changes in the legislation for the criteria for the small business definition in 2008 and in 2012. The correlation between the sales volume of the small business and the local budget revenues of Ukraine is analyzed. In order to evaluate the certainty of the small business development trends and its impact on local budget revenues, the same analysis was done on the basis of the indicators calculated in the currency equivalent.
\end{abstract}

Keywords

small business, local budget revenues, sales volume, criteria for small businesses definition

JEL Classification L6, P44

\section{INTRODUCTION}

Small business as a business entity is a payer of taxes and fees to the state and local budgets, it makes a contribution to budgets' financial resources. In turn, financially strong regions provide resources to support both the population and business. The welfare of the whole country and regions depends on the development of small business. That is why analysis of the development of small business as a subject of accumulation of local budget revenues is particularly topical in the context of the socio-economic and political crisis.

The impact of small business development on the country's economic growth is difficult to be overestimated. In the developed countries, the small business produces up to $60 \%$ of GDP, provides up to $70 \%$ of workplaces and acts as an engine for innovation development. In Ukraine, $97 \%$ of all business entities are represented by small enterprises, but they provide only $18 \%$ of the sales volume of the country, and employ only $26 \%$ of the labor force (State Statistics Service of Ukraine, n.d.).

The development of small business in Ukraine shows the opposite trends: the number of small enterprises tends to increase, the number of employees in one small enterprise decreases each year, and its portion in sales volume decreases or grows slowly, even though the number of these enterprises increases each year. 
There is a necessity to evaluate the certainty of small business development as a factor in socio-economic development and the budget-generating source.

The objective of the article is to analyze the trends of small business development and to evaluate the certainty of its influence on the local budget revenues in Ukraine.

\section{LITERATURE REVIEW}

First of all, it is necessary to define the small business according to Ukrainian legislation. Since January 1,2018 , small entrepreneurship is presented by enterprises that do not meet the criteria for microenterprises and where indicators match two of the following criteria: net book value - up to 4 million euros; net revenue (goods, works, services) - up to 8 million euros; average number of employees - up to 50 persons (The law of Ukraine "Concerning the introduction of amendments to the law of Ukraine "On Accounting and Financial Reporting in Ukraine" on improving some of the provisions (2017, No 2164-VIII)).

Also the Budget Code defines budget revenues as tax, non-tax and other revenues, which are received irrecoverable according to the legislation of Ukraine (Budget Code of Ukraine, 2010).

A lot of publications are devoted to the analysis of small business activity.

Kornecki (2006) considers the macroeconomic aspects of small business development in the Polish economy, such as the number and size of commercial firms, the share of small and medium business in GDP, its share in national employment and foreign trade. The research shows that small business development plays a very important role in the development of Poland.

Exploring the barriers to the development of small, medium and micro enterprises operating in the South Africa, Donga, Ngirande, and Shumba (2016) mark the following: the lack of funding and market access, presence of outdated equipment and technology, weak infrastructure and absence of training. As a result of a business owners survey, Sitharam and Hoque (2016) identified factors which make an influence on doing business efficiency: crime and corruption. The fact that small business in South Africa does not have the proper preparation for business or- ganization and often does not use basic accounting practices, which limits access to necessary information for management decision making, is also proved by Sibanda and Manda (2016). The authors show how non-compliance with the proper accounting practices can negatively affect the financial indicator's of SMEs and contribute to their inevitable failure.

The problems of small business development in Ukraine were defined by the Center for Civic Expertise (The Centre of international private entrepreneurship. The roadmap of entrepreneurial development in Ukraine: 2015-2016, 2014), they are: inequality of relation rights between SME and public authorities; corruption in public authorities; excessive regulation of economic activity; limited and non-transparent access to state and communal resources; inefficiency of mechanisms for protecting the rights and legitimate interests of SMEs.

Also in USAID report of business climate in Ukraine (USAID, 2016), it is noticed that making easier the state administrative burden in 2015 will promote stimulation and activation of small and medium businesses development in Ukraine in the coming years. In comparison with 2012, entrepreneurs notice the lack of obstacles with business registration and pay attention to improvements in the situation with all-time audits in 2015. It was also noted in the report that during last two years, more than $50 \%$ of the surveyed companies had some innovations: $29 \%$ of companies had informed about product rollout, $19 \%$ of companies had been continuing the implementation of new management methods, $18 \%$ had begun using the new methods of promotion and marketing, and one of ten small and medium enterprises in Ukraine had been engaged in foreign economic activity.

At the same time, Matviyishyn and Mahats (2015) note that since small enterprises in Ukraine are considered to be business entities with an annual income of up to 10 million euros, the development of small businesses, in particular the number of small 
enterprises, depends on the speed of changes of Ukrainian hryvnia rate exchange. Also, the authors pay attention to a significant reduction in the number of employed in small business, which is related to the decrease in the number of population, caused by the socio-political conflict and the general economic downfall.

A number of important steps have been taken for small business development in Ukraine: the Strategy for Sustainable Development "Ukraine 2020 " was adopted, the necessity of deregulation and entrepreneurship development was allocated in the development vector, Ukraine has taken part in the program "Horizon - 2020" concerning the development of innovation and competitive ability of enterprises by financing the new technologies and materials creation and their implementation into small and medium business, Ukraine has taken part in the program "European Network of Enterprises", which is aimed at strengthening investment and trade opportunities for enterprises at the expense of business partners and investors search for international trade or the creation of joint ventures (Apostoliuk, 2016).

Nevertheless, analyzing the small business development in Ukraine, Byrntska (2015) concludes that the dynamics of the development of small and medium business indicates a deterioration in this sector of economy. All indicators, except the average wage, which increased over the period under review due to minimum wages increase, show the growth of negative trends. The sales volume decreases because of consumer demand decrease in the domestic and foreign markets, labor liberation, underdevelopment of infrastructure, increase of the number of unprofitable enterprises because of decreasing motivation of creation of new enterprises, etc.

Palyvoda and Temindarov (2015) came to the conclusion that in Ukraine, pre-crisis indicators of small business (the number of enterprises and employment) have not been restored by now, which is caused not only by the consequences of the financial crisis, but also by the impact of socio-political situation on its development. Tkachenko and Koliadenko (2016) note that according to the results of 2015, the domestic sector of small business lags behind the economically developed countries by $2-8$ times by the main macroeconomic indicators.
Olvinska (2015) classifies the Ukrainian regions according to the level of small business development: very low, low, medium, high, very high. The largest specific weight, more than $60 \%$ of the regions, for the whole period under consideration, is observed in the regions with very low and low levels of small business development (Olvinska, 2015).

Danylkiv classifies the most developed regions according to the index of small business development: Kyiv, Dnipropetrovsk, Odesa, Kharkiv regions. The lowest rates are in Chernivtsi, Volyn, Zhytomyr, Zakarpattia, Sumy, Rivne, Ternopil regions. The average level is in all other regions (Vinnytsia, Zaporizhznia, Ivano-Frankivsk, Kyiv, Kirovohrad, Mykolaiv, Poltava, Kherson, Khmelnytskyi, Cherkasy and Chernihiv regions) (Danylkiv, 2015). It should also be noted that the level of small businesse development in the Donetsk and Luhansk regions is reduced due to the deterioration of the socio-political situation.

Consequently, the scientific papers contain an analysis of the main indicators of small business development: the number of registered small business entities, the number of persons employed in small businesses and employees, and the sales volume of small business. But even a complex of these indicators does not always allow to make an objective analysis of small business because of the instability of the criteria for defining the businesses as small, accompanied by appropriate changes in the collection of statistical data and their reflection. Few investigated questions remain the reality of trends in the development of small business and its impact on the formation of local budgets revenues.

The reality of trends in the development of small business and its impact on the formation of local budget revenues continue to be not enough investigated.

\section{RESULTS OF DATA ANALYSIS}

Small entrepreneurship is an indispensable attribute of the modern economic system in each state, however, the criteria for defining an economic entity as small are different in each country. Thus, the basis for determining the small business entity can be the number of employees (Poland, Italy, Hungary), type 
of economic activity (France, Japan), net revenue (Great Britain, Czech Republic). The criteria for determine the entities as small ones in Ukraine corresponded to German: number of employees and sales income (Vynnychenko \& Zavgorodnia, 2012). Until December 31, 2017 it was specified in the Commercial Code of Ukraine that small business entities are individuals and legal bodies - economic entities of any organizational and legal form and ownership, whose average number of employees for the reporting period (calendar year) does not exceed 50 persons and whose annual income from any activity does not exceed the amount equivalent to 10 million euros, determined by the average annual rate of the National Bank of Ukraine (Commercial Code of Ukraine, 2003).

Since January 1, 2018, according to the Law of Ukraine "Concerning the introduction of amendments to the law of Ukraine "On Accounting and Financial Reporting in Ukraine" on improving some of the provisions" (dated on October 5, 2017 No. 2164-VIII) small business is presented by entern prises that do not meet the criteria for microenterprises (net book value - up to 350 thousand euros, net revenue (goods, works, services) - up to 700 thoun sand euros, the average number of employees - up to 10 people), which indicate the date of preparation of the annual financial statements for the year, which precede the reporting one, match two of the following criteria:

- net book value - up to 4 million euros;

- $\quad$ net revenue (goods, works, services) - up to 8 million euros;

- average number of employees - up to 50 persons.

Analyzing the impact of small business on the country's development, it is necessary to mark two main aspects of its manifestation: socioeconomic and financial. The financial one is that small business as a business entity pays state and local taxes and fees, strengthening the financial position of the region. Socio-economic aspect is that due to entrepreneurial activity, the level of population employment and its welfare are increased, the supply of goods and services, peculiar to the specifics of regional markets development, is provided, and scientific and technological development is stimulated. The necessity of making investment into a regional economy is reduced significantly. Furthermore, small business contributes to decrease of unemployment. Thus, in 2016, 1.6 million people in Ukraine were employed in small business (State Statistics Service of Ukraine, n.d.). Consequently, upon condition that at each registered company, there is at least 1 person, the state reduced the potential expenses for unemployment benefits, the minimum amount of which was UAH 544 million, on average by UAH 870 million. Thus, the socio-economic effect of the small business impact on the country's development is evident.

In spite of the fact that even in economically developed countries the influence of small business on local budget revenues plays less role than on the socioeconomic development, in this article, we are going to analyze the dynamics of small business development as a factor of the formation of local budget revenues. The main indicator, which characterizes the development of small business, is the sales volume (Figure 1).

Analyzing the statistical data, presented in Figure 1, it is possible to note a static dynamics of indicators of small business development. So, in 2005-2006, there is a sharp increase in sales volume. Such a sharp rise is not provided by acceleration of the small business development, but due to implementation of changes into the criteria for their definition. The Law of Ukraine "Concerning the introduction of amendments to certain legislative acts of Ukraine on business regulation" dated September 18, 2008 No. 523VI became effective as a result of Ukraine's entrance to the European Business Register in 2008.

In order to adapt Ukrainian standards to international requirements, the criteria for defining enterprises as small ones were revised. The annual income has been increased from 500 thousand euros at the rate of the NBU (according to Article 55 of the Commercial Code of Ukraine (2003) to UAH 70,000 million. Thus, statistical data published after the document entered into force (taking into account the revision of the indicators since 2006) show a sharp revival of the small business activity, which does not correspond to reality by its economic sense. Entrepreneurship continued to develop gradually, but enterprises with larger volumes of annual income came into the focus of the collection of statis- 
Source: Developed by the authors based on State Statistics Service of Ukraine (n.d.), Osaulenko (2011).

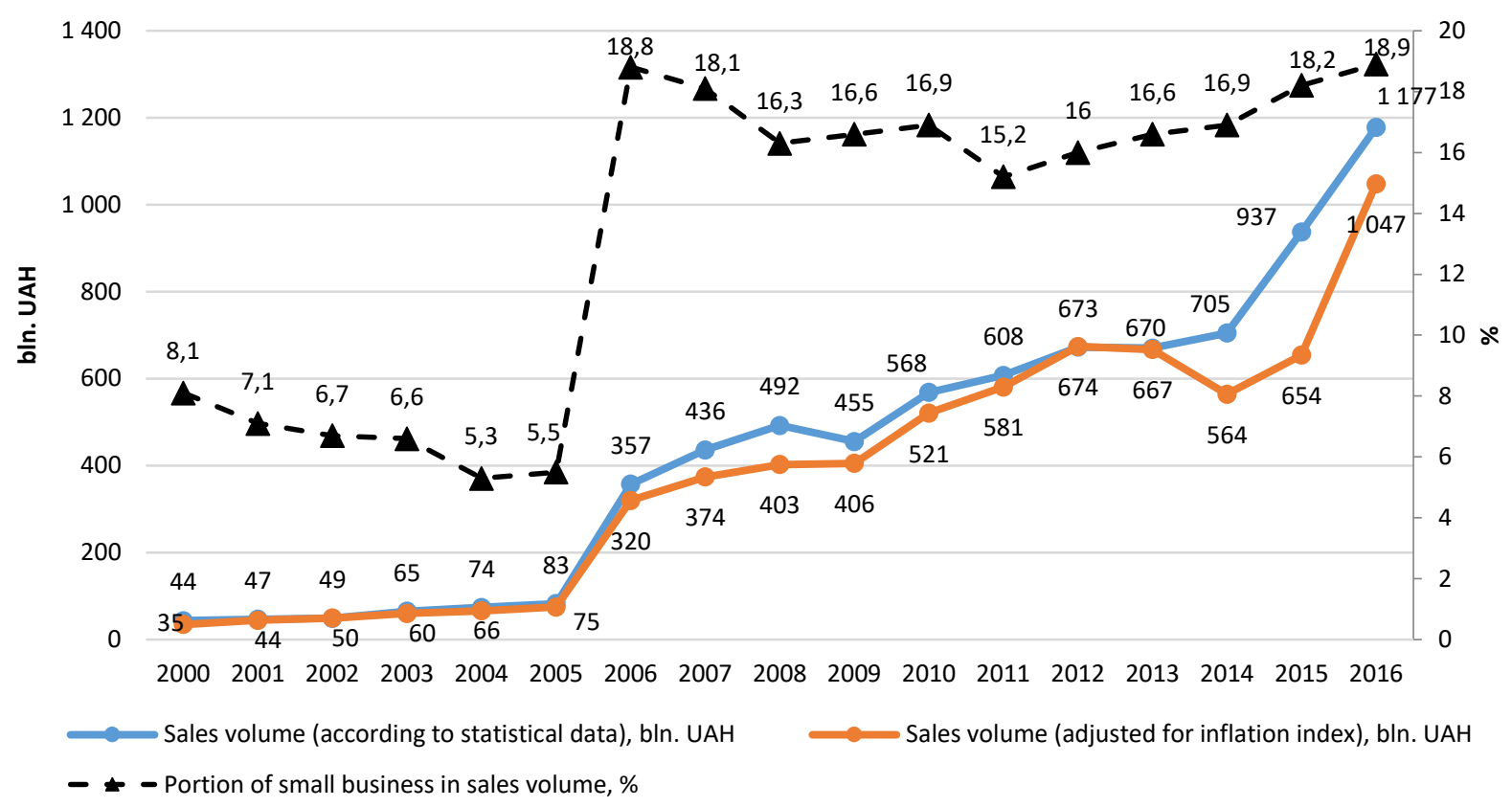

Figure 1. The sales volume of small business and the portion of small business in the sales volume of Ukraine in 2000-2016

tical data, which provided a significant increase in the sales volume of small businesses in general.

The next 'downfall' in the trend in $2008-2009$ is determined by the reduction of entrepreneurial activity due to the negative effects of the global financial crisis in Ukraine (objective reality).

Here should be also noted the growth of sales volumes during 2011-2012 due to the Law of Ukraine "Concerning development and state support of small and medium business in Ukraine" dated on March 22, 2012 No. 4618-VI becoming effective. According to the Law, to small enterprises it began to attribute the economic entities with an annual income of 10 million euros (instead of USD 70 million), which again provided the collection of statistical data on the activities of business entities with greater turnover (Dmytriyera, Zakharchuk, 2011).

The decrease of sales in 2014 is determined by manifestation of the socio-political crisis in the country. The growth of sales volumes in 2015 is determined by cheapening of the national currency, rising prices of goods sold and, as a result, an increase in sales volumes in monetary terms.
In order to eliminate inconsistencies over the criteria for small enterprises definition and receive a statistical series of comparative data, we will make the alignment of the statistical series taking into account changes in the legislation in 2008 and 2012. First of all, we will make the aligning of the statistical series by 2006 .

At first, it is necessary to see how the sales volume changes during the time or calculate the linear relationship between sales volume and the time indicator in 2000-2005:

$$
Y=8,372 \cdot t+31,175
$$

where $Y$ - sales volume of small business, $t$ time indicator.

The model is adequate to the observational evidence (given error is 0.05 ) and has significant parameters. By substituting the time index into the formula (1), we calculate the estimated value of the sales volume. The calculated value in 2006 is UAH 89,783 billion.

Next step is to calculate the adjustment ratio of the sales volume according to the statistical data to the empirically calculated sales volume: 
Table 1. Sales volume of small business during 2000-2006, adjusted for 2006

Source: Developed by the authors based on State Statistics Service of Ukraine (n.d.), Osaulenko (2011).

\begin{tabular}{l|c|c|c|c|c|c|c}
\hline \multicolumn{1}{c|}{ Year } & $\mathbf{2 0 0 0}$ & $\mathbf{2 0 0 1}$ & $\mathbf{2 0 0 2}$ & $\mathbf{2 0 0 3}$ & $\mathbf{2 0 0 4}$ & $\mathbf{2 0 0 5}$ & $\mathbf{2 0 0 6}$ \\
\hline Sales volume (according to statistical data), UAH bln. & 43,8 & 47,2 & 49,4 & 65,2 & 74,4 & 82,9 & 357,3 \\
Sales volume (adjusted for 2006), UAH bln. & 174,3 & 187,7 & 196,5 & 259,4 & 295,9 & 330,0 & 357,3 \\
\hline
\end{tabular}

$$
k=\frac{357,3}{89,8}=3,979
$$

Then the sales volume during $2000-2005$ is updated according to the calculated index. The received statistical set of data aligned according to the changes in small business definition in 2008 is presented in the Table 1.

In the same way, the statistical set of data is aligned up to 2011. The statistical set of comparable data taking into account the changes in legislation in 2008 and in 2012 is presented in Figure 2.

Consequently, the adjusted statistical set of data were received, which makes it possible to consider the development of small business in 2000-2016 and to describe it as gradual, stable and confident. Deceleration in economic activity occurs only in the crisis years 2009 and 2014. However, the analysis of the small business development cannot be considered complete without considering it through the lens of the national currency.

The adjusted statistical set of data of small business sales volume calculated in national currency and in dollars is presented in Figure 3.
Using the data of Figure 3 it is possible to conclude that the sales volume of small business during 2000-2016 has a tendency to increase in Ukraine except for 2014. At the same time, comparing sales volume of small business, calculated in the national currency and in dollars, it forces us to dispute the certainty of small business development. Taking into account the cheapening of the national currency in 2008 from UAH 5.45 to 7.99 for 1 USD and in 2014 from 7.99 to 11.89 UAH for 1 USD (in 2017 - 28.06 UAH for 1 USD) (according to official statistics from State Statistics Service of Ukraine, which are also not fully reliable), the cost of goods sold by small business (and other business entities) has increased significantly.

But to increase the prices proportional to the increase in the costs of raw materials (services) proved to be impossible due to the limited purchasing power of consumers. The reducing of net goods or complex of services provided solved the problem only partly. The opportunity of enterprises to use imported products has reduced, and the opportunity of consumers to buy imported products has reduced.

Nevertheless, the uptrend to sustainable development of small business is questionable, it is not only engaged in keeping the social and econom-

Source: Developed by the authors based on State Statistics Service of Ukraine (n.d.), Osaulenko (2011).

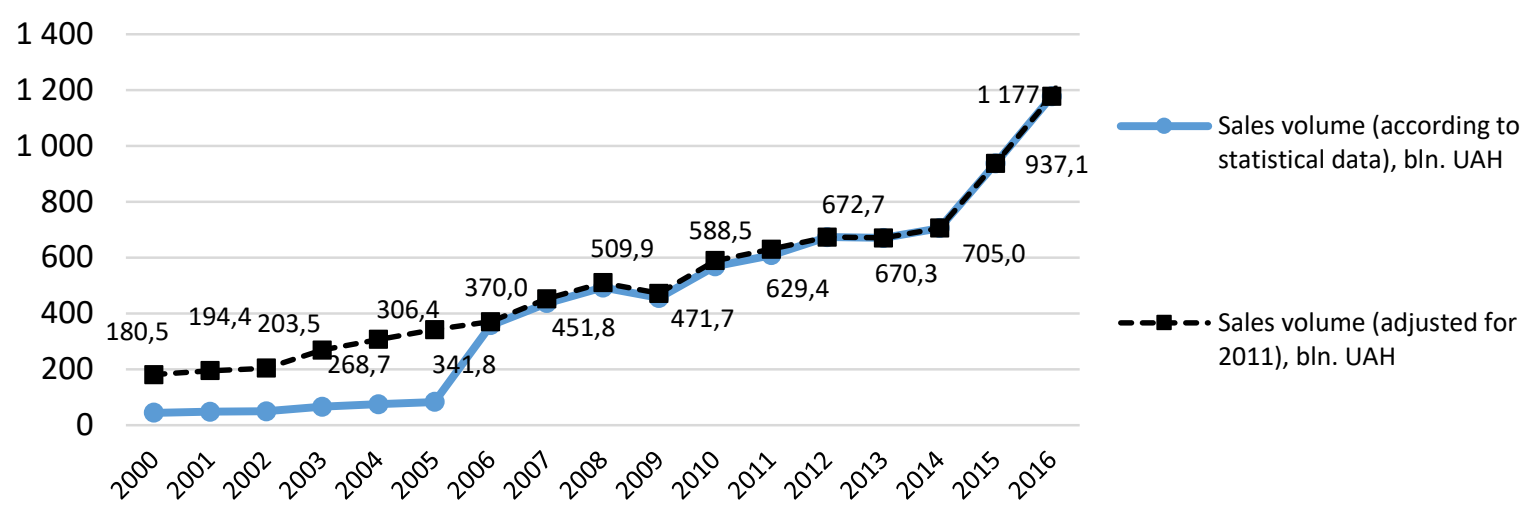

Figure 2. The sales volume of small business of Ukraine in 2000-2016 taking into account the changes in legislation in 2008 and in 2012 


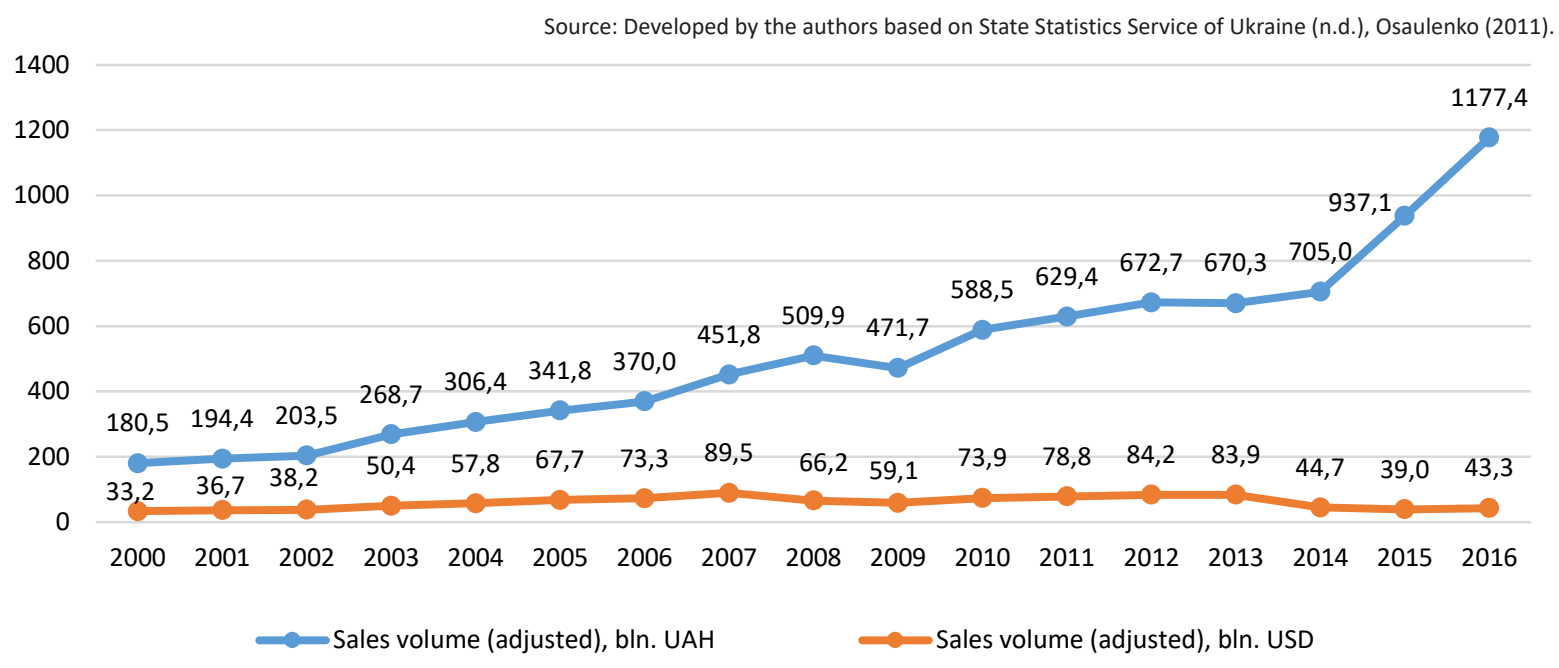

Figure 3. Adjusted statistical set of data of small business sales volume in 2000-2016 calculated in national currency and in dollars

ic welfare of the state, but also makes an impact on the country's financial growth. Since there is no separate accounting for return of duties from small business entities, it should be noted that the main indicator of the impact of small business activity on local budget revenues is a single tax. Also small business entities pay other taxes and fees (such as the income tax (for legal entities), property tax, environmental tax, travel tax and parking fees, etc.), but the part of taxes and fees paid by small business entities cannot be obtained from financial reports of State Fiscal Services. Therefore, it makes economic sense to analyze the correlation between the local budget revenues of Ukraine and the sales volume of small business. An analysis of the linear relationship between the revenues of local budget of Ukraine and the sales volume of small business, taking into account changes in legislation in 2008 and 2012, is shown in Figure 4.

The analysis of data presented in Figure 4 makes it possible to conclude that with a determination factor of $97.18 \%$, there is a direct significant correlation between the revenues of local budgets of Ukraine and the sales volume of small business. The model is adequate to the observational evidence $($ Femp $=517,5>F(0,05 ; 1 ; 15)=4,5)$ and has significant parameters

$$
\left(t_{1}=22,7, t_{0}=-3,6>t(0,05 ; 14)=2,1\right) \text {. }
$$

Thus, small business takes part in the formation of local budget revenues in Ukraine.

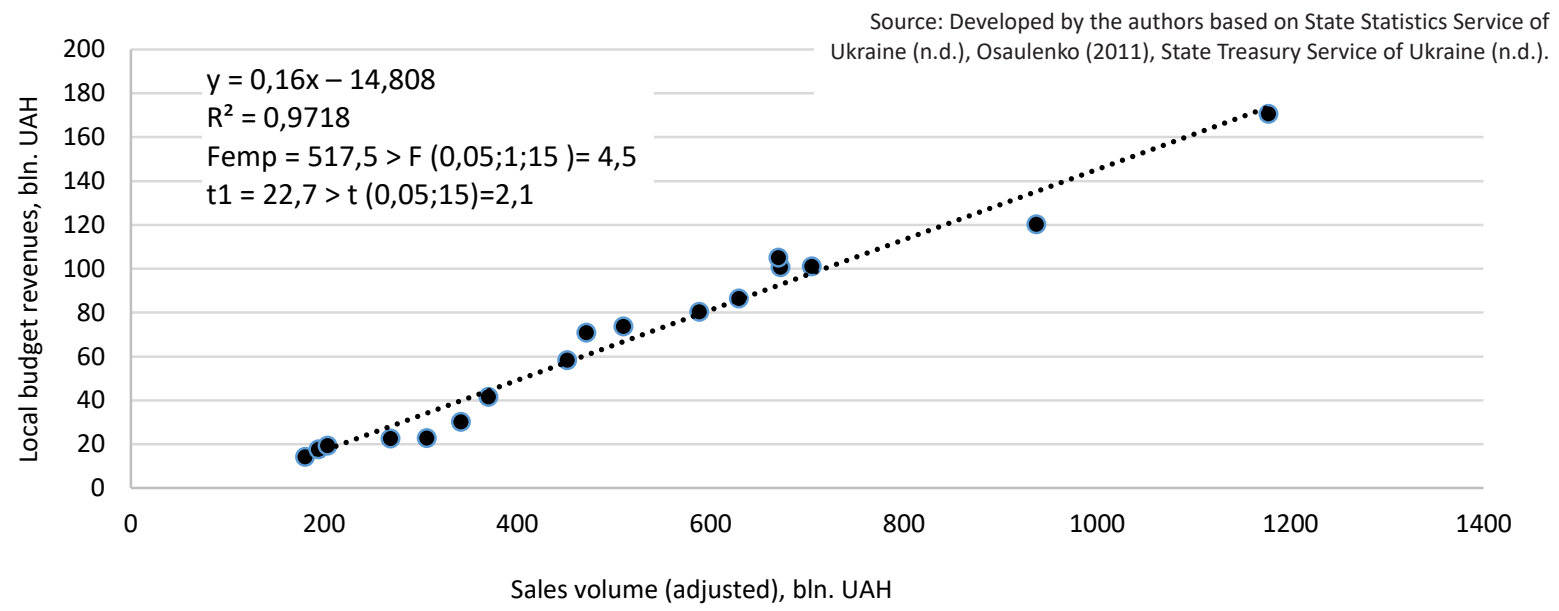

Figure 4. Linear relationship between the revenues of local budgets of Ukraine and the sales volume of small business, taking into account changes in legislation in 2008 and 2012 


\section{CONCLUSION}

The analysis allows to make the following conclusion. It was found that the dynamics of the sales volume of small business in Ukraine according to the statistical data is characterized by a jump-like growth in 2006 and 2011. It is explained by changes in the criteria of definition of the small business (namely increasing the maximum amount of annual revenue), and its reduction in 2009 and 2014, caused by general economic decline affected by the financial and socio-political crises.

The statistical series alignment made it possible to characterize the dynamics of the sales volume of small business, calculated in national currency, as gradually increasing, and represented in foreign currency (in US dollars) as reducing trend.

At the same time, direct significant correlation between the sales volume of small business and the local budget revenues of Ukraine was found, which confirms the actuality of small business development impact on the formation of local budget revenues.

\section{REFERENCES}

1. Apostoliuk, O. (2016). The priorities of state financial support of small business in Ukraine. Effective economy, 7. Retrieved from http://www.economy.nayka. com.ua/?op $=1 \& \mathrm{z}=5085$

2. Bernytska, D. (2015). The issues of development of small and medium entrepreneurship in modern realities. Regional aspects of development of productive forces of Ukraine, 20, 21-26.

3. Budget Code of Ukraine (2010). Retrieved from http://zakon2.rada. gov.ua/laws/show/2456-17

4. Commercial Code of Ukraine (2003). Retrieved from http://zakon4.rada.gov.ua/laws/show/436-15

5. Danylkiv, Kh. (2015). Assessment of Regional Development of Small Entrepreneurship in Ukraine. Retrieved from http://nbuv.gov.ua/ UJRN/svitfin_2015_2_17

6. Dmytriyera, V., Zakharchuk, Ya. (2011). The trends in the small businesses development in Ukraine: taking into account the specifics of these statistical sources. Economic analysis, 8, 66-73.

7. Gift Donga, Hlanganipai Ngirande, \& Knowledge Shumba (2016). Perceived barriers to the development of small, medium and microenterprises: a case study of Thulamela Municipality in the
Limpopo Province. Problems and Perspectives in Management, 14(4), 61-66. http://dx.doi.org/10.21511/ ppm.14(4).2016.07

8. Jubilant J. Sibanda, \& David Charles Manda (2016). Symptoms of accounting practices that contribute to small business failures. Problems and Perspectives in Management, 14(4-1), 194-202. http://dx.doi. org/10.21511/ppm.14(4-1).2016.08

9. Kornecki, L. (2006). The Role of Small Business Development in Stimulating Output and Employment in the Polish Economy. Problems and Perspectives in Management, 4(1), 32-39. Retrieved from https://businessperspectives. org/journals/problems-and-perspectives-in-management/issue-11/ the-role-of-small-business-development-in-stimulating-outputand-employment-in-the-polisheconomy

10. Matviyishyn, Y., Mahats, T. (2015) Freatures of small business development in Ukraine. Journal of Geography, Politics and Society, 5(2), 25-33.

11. Olvinska, Yu. (2015). Regional specifics of small business development in Ukraine. In Prospects of economic development in the global crisis: collection of scientific articles (pp. 304-309). Bulgaria: Academic Publishing House of the Agricultural University Plovdiv.
12. Osaulenko, O. (2011). Statistical abstract of Ukraine 2010. State Statistics Service of Ukraine. Kyiv: DP "Inform. analytic. agency".

13. Palyvoda, O., Temindarova, Yu. (2015). The Development of Smal and Medium Business in Ukraine in the Context of European Economic Integration. Businessinform, 11, 267-271.

14. Sharmilee Sitharam, \& Muhammad Hoque (2016). Factors affecting the performance of small and medium enterprises in KwaZulu-Natal, South Africa. Problems and Perspectives in Management, 14(2-2), 277-288. http:// dx.doi.org/10.21511/ppm.14(22). 2016.03

15. State Statistics Service of Ukraine (n.d.). Entrepreneurial development (2010-2016). Retrieved from http://www.ukrstat.gov.ua/

16. State Treasury Service of Ukraine (n.d.). Progress report on State budget. Retrieved from http://www. treasury.gov.ua/

17. Tax Code of Ukraine (2010). Retrieved from http://zakon. rada.gov.ua/cgibin/laws/main. cgi?nreg=2755-17

18. The Centre of international private entrepreneurship. The roadmap of entrepreneurial development in Ukraine: 2015-2016 (2014). Kyiv: The Centre of public evaluation. 
19. The law of Ukraine. Concerning the introduction of amendments to certain legislative acts of Ukraine on business regulation (2008, September 18). Retrieved from http://zakon2.rada.gov.ua/ laws/show/523-17

20. The law of Ukraine. Concerning the introduction of amendments to the law of Ukraine "On Accounting and Financial Reporting in Ukraine" on improving some of the provisions (2017, October 5).
Retrieved from http://zakon2.rada. gov.ua/laws/show/2164-19

21. The law of Ukraine. Concerning development and state support of small and medium business in Ukraine (2012, March 22). Retrieved from http://zakon1.rada. gov.ua/laws/show/4618-17

22. Tkachenko, T., Koliadenko, I (2016). Specifics of small business development in Ukraine. Current issues of economics and entrepreneurship, 18.
23. USAID (2016). The Annual Business Climate Assessment in Ukraine 2015 (based on the SMEs survey results). Retrieved from http://lev.org.ua/en/articles/ ABCA2015.html

24. Vynnychenko, V., Zavgorodnia, V. (2012). Definition of subjects of small and medium enterprises according to the legislation of Ukraine. Retrieved from http:// www.bulletin.uabs.edu.ua/store/ jur/2012/ 8a4ab128e673ec7b47aba3608950ec79.pdf 